\title{
REPRESENTASI MASKULINITAS DALAM RITUAL ETU DI KAMPUNG ADAT TUTUBHADA KABUPATEN NAGEKEO, NUSA TENGGARA TIMUR
}

\section{THE REPRESENTATION OF THE MASCULINITY IN THE RITUALS OF 'ETU' IN KAMPUNG ADAT TUTUBHADA IN NAGEKEO REGENCY, EAST NUSA TENGGARA}

\author{
Adinda Sanita Putri Khinari ${ }^{1}$, Ni Made Yuni Sugiantari ${ }^{2}$, Dania Nabila Lubis ${ }^{3}$, \\ Ni Kadek Ari Marlina ${ }^{4}$, Ni Putu Indah Juliyanti ${ }^{5}$, A. A. Ayu Isna Surya Dewi ${ }^{6}$, \\ Rochtri Agung Bawono ${ }^{7}$ \\ 1,2,3,4,5,6 Mahasiswa Pecinta Alam "Wanaprastha Dharma" Universitas Udayana \\ Jalan Doktor Goris Nomor 7A Denpasar 80234 \\ ${ }^{7}$ Universitas Udayana \\ Jalan Pulau Nias Nomor 13 Denpasar 80114 \\ e-mail:9g.adindasanita@gmail.com,yunisugiantari00@gmail.com, nabilaputridania@gmail.com, \\ arimarlina07@gmail.com, indahjuliyanti44@gmail.com, isnasurya93@gmail.com, \\ rabawono@gmail.com
}

Naskah Diterima: 29 September $2020 \quad$ Naskah Direvisi: 15 Maret $2021 \quad$ Naskah Disetujui :30 April 2021

DOI: 10.30959/patanjala.v13i1.677

\begin{abstract}
Abstrak
Etu atau tinju tradisional yang dilaksanakan di Kabupaten Nagekeo merupakan salah satu tahapan dari ritual pasca panen (Gua Meze). Etu dipercaya sebagai ungkapan rasa syukur masyarakat lokal atas berkah dalam panen musim panas dan wujud bagi kaum laki-laki untuk mempresentasikan kembali maskulinitas dirinya melalui Etu. Penelitian di Kampung Adat Tutubhada Desa Rendu Tutubhada Kecamatan Aesesa Selatan Kabupaten Nagekeo dilakukan dengan tujuan untuk mengetahui bagaimana representasi maskulinitas seorang laki-laki pada ritual Etu. Penelitian ini menggunakan pendekatan kualitatif deskriptif. Sumber data disusun berdasarkan studi pustaka penelitian terdahulu, pengamatan di lapangan, wawancara, dan dokumen. Hasil yang dicapai dalam penelitian ini adalah penjelasan mengenai rangkaian, pelaku, perlengkapan, dan aturan dari Etu di Kampung Adat Tutubhada, eksistensi Etu di masa kini, serta bagaimana Etu dapat merepresentasikan maskulinitas laki-laki selaku pelaku ritual.
\end{abstract}

Kata kunci: tinju trasidisional, representasi, maskulinitas, laki-laki, syukur panen

\section{Abstract}

'Etu', which is a traditional form of ceremonial boxing practiced in Nagekeo Regency, is one stage of the post-harvest rituals Gua Meze. 'Etu' is believed to be a form of expression of gratitude offered by the local community for the blessings that have been received in the harvest and at the same time also serves as a form to represent the masculinity. The research which has been conducted in Kampung Adat Tutubhada - which is situated in the village of Rendu Tutubhada in South Aesesa District, Nagekeo Regency - aims to reveal how the masculinity is represented in 'Etu'. The research used the descriptive qualitative method. Sources of data in the research were compiled based on the literature study of previous research, field observations, interviews, and documents. The results achieved in this study explain in detail 'Etu' in Kampung Adat Tutubhada 
that includes a sequence of activities, performers, equipment, and rules, the current existence of 'Etu' as well as to draw how 'Etu' can represent the masculinity of men as the ritual performers.

Keywords: traditional boxing, men, identity, existence, harvest festival

\section{A. PENDAHULUAN}

Indonesia merupakan negara yang memiliki keberagaman budaya. Indonesia memiliki total 1.340 suku bangsa yang tersebar dari Sabang sampai Merauke. Salah satu suku bangsa tersebut yaitu suku Rendu yang berada di Nusa Tenggara Timur (BPS Indonesia, 2010). Nusa Tenggara Timur memiliki 22 kabupaten/kota yang tersebar di berbagai pulau dengan tiga pulau besar di antaranya yaitu Pulau Sumba, Pulau Timor, dan Pulau Flores. Di Pulau Flores terdapat salah satu kabupaten yang masih memegang erat kebudayaan dan kepercayaannya yaitu Kabupaten Nagekeo.

Kepercayaan masyarakat mengenai keberadaan leluhur terdahulu di Kabupaten Nagekeo masih sangat kental. Kabupaten Nagekeo juga memiliki ragam budaya berupa benda maupun takbenda yang masih diterapkan oleh masyarakat lokal di zaman modern ini. Banyak kebudayaan di Kabupaten Nagekeo yang belum terekspos secara luas dan apabila dikembangkan dapat menjadi sesuatu yang dapat mendukung kesejahteraaan masyarakatnya. Namun, dokumentasi berupa gambar maupun tulisan mengenai aktivitas budaya ini, masih sangat minim. Hal inilah yang membuat peneliti melakukan penelitian lebih dalam mengenai Etu atau tinju tradisional yang menjadi salah satu ritual kebanggaan masyarakat, sehingga dapat memperkuat keberadaan Etu sebagai salah satu warisan budaya takbenda yang telah ditetapkan oleh Kementerian Pendidikan dan Kebudayaan pada tahun 2015 dengan nomor registrasi 201500253 (Sada, 2019).

Menurut ilmu antropologi, kebudayaan adalah keseluruhan sistem gagasan, tindakan dan hasil karya manusia dalam kehidupan masyarakat yang dijadikan milik diri manusia dengan belajar (Koentjaraningrat, 2009: 153).
Ritual Etu merupakan salah satu bagian dari kebudayaan tersebut. Melihat bahwa ritual ini hanya dapat diperankan oleh lakilaki, peneliti tertarik untuk meneliti bagaimana representasi maskulinitas seorang laki-laki pada ritual Etu.

Etu di Kampung Adat Tutubhada ini dilaksanakan pada bulan Juni atau Juli yang dipercaya sebagai ungkapan rasa syukur masyarakat lokal kepada leluhur atas berkah dalam panen musin panas. Etu juga ditujukan bagi kaum laki-laki untuk melakukan baku hantam di dalam arena yang telah dipersiapkan sebelumnya. Baku hantam tersebut merupakan salah satu bentuk olahraga tradisional di Indonesia yang termasuk dalam objek kebudayaan menurut UU RI No. 5 Tahun 2017 tentang Pemajuan Kebudayaan. Menurut Laksono sebagaimana dikutip oleh Dewi Primawati Susanti (2014) dijelaskan bahwa olahraga tradisional harus memenuhi dua persyaratan yaitu berupa olahraga dan bagian dari aktivitas budaya, baik berupa tradisi, maupun ritual adat yang berkembang selama beberapa generasi, atau sesuatu yang terkait dengan tradisi budaya suatu bangsa secara lebih luas.

Ritual Etu termasuk ke dalam nilai budaya yang merupakan bagian dari sistem budaya. Dalam kaitan itu, sistem nilai budaya adalah sejumlah pandangan mengenai soal-soal yang paling berharga dan bernilai dalam hidup. Sistem nilai budaya menjiwai semua pedoman yang mengatur tingkah laku warga pendukung kebudayaan yang bersangkutan. Pedoman tingkah laku itu adalah adat-istiadatnya, pandangan hidup dan ideologi pribadi (Budiman, 2013). Kaitannya dengan Etu, yaitu olahraga yang memperlihatkan baku hantam di arena tinju ini tetap memiliki aturan-aturan yang mengedepankan nilai kebudayaan demi terlaksananya ritual syukur panen di Kampung Adat 
Tutubhada.

Etu tidak hanya dimainkan oleh lakilaki dewasa saja, namun anak laki-laki juga melakukan olahraga tinju ini. Dalam melakukan olahraga ini, tidak ada keseriusan yang terjadi, sehingga dapat dikatakan permainan yang bertujuan untuk melatih keberanian dari anak laki-laki saat sudah dewasa nanti. Berdasarkan perbedaan sifat permainan, Roberts, Arts, dan Bush sebagaimana dikutip oleh Danandjaja (2002) mengungkapkan bahwa permainan rakyat (folk games) dapat dibagi menjadi dua golongan besar, yaitu permainan untuk bermain (play) dan permainan untuk bertanding (game). Melihat hal tersebut, Etu yang melibatkan anak-anak ini termasuk ke dalam golongan bermain karena Rusmana (2010) mengatakan bahwa sebelum permainan berkembang menjadi sebuah perilaku yang bermakna, bermain merupakan bagian dari sebuah ritual budaya dan agama sehingga anak-anak yang terlibat menunjukkan bentuk ekspresi dan kelebihan energi sekaligus mengikuti sebuah rangkaian budaya.

Etu di Kampung Adat Tutubhada menjadi ritual tahunan yang dilaksanakan karena masyarakat lokal menganggap ritual ini sakral dan harus dilaksanakan. Masyarakat setempat percaya bahwa apabila ritual tidak terlaksana, dapat menimbulkan malapetaka yang akan menimpa daerah tersebut, (Kalvaristo, 2007). Hal ini menandakan bahwa masyarakat lokal masih menjunjung tinggi unsur-unsur kebudayaan.

Berdasarkan latar belakang tersebut, rumusan masalah yang diangkat dalam penelitian ini yaitu bagaimana representasi maskulinitas dalam ritual Etu. Penelitian ini bertujuan untuk menjelaskan secara deskriptif mengenai peran laki-laki yang dipresentasikan kembali berdasarkan ritual ini. Penelitian ini dapat bermanfaat sebagai bahan komparasi untuk penelitian serupa dan pengembangan selanjutnya pada Etu. Batasan permasalahan pada penelitian ini adalah peran laki-laki di dalam proses pelaksanaan Etu dan lokasi penelitian yang hanya berfokus di Kampung Adat Tutubhada.

Sesuai dengan judul penelitian dapat dijelaskan bahwa representasi menurut Chris Barker adalah kajian utama dalam cultural studies yang mengartikan sebagai langkah dalam mengkonstruksikan secara sosial tentang penyajian makna kepada masyarakat dan oleh masyarakat di dalam pemaknaan yang berbeda. Dalam kajian kebudayaan ini tentu saja akan lebih fokus pada individu tentang bagaimana proses pemaknaan sebuah arti masalah sosial/fakta sosial terhadap representasi (pemaknaan setiap individu-individu). Kemudian, maskulinitas dapat dijelaskan sebagai peran sosial, perilaku dan maknamakna tertentu yang dilekatkan pada lakilaki. Menurut Barker (2001) maskulin merupakan sebuah bentuk konstruksi kelelakian terhadap laki-laki. Laki-laki tidak dilahirkan begitu saja dengan sifat maskulinnya secara alami, maskulinitas dibentuk oleh kebudayaan. Hal yang menentukan sifat perempuan dan laki-laki adalah kebudayaan. Secara umum, maskulinitas tradisional menganggap tinggi nilai-nilai antara kekuatan, kekuasaan, ketabahan, aksi, kendali, kemandirian, kepuasan diri, kesetiakawanan laki-laki, dan kerja.

Penelitian pertama yang menjadi rujukan adalah penelitian oleh Kalvaristo pada tahun 2007 yang berjudul Ritual Etu Masyarakat Kampung Olaewa Flores 1978-1981. Dalam penelitian tersebut peneliti berfokus pada sejarah perkembangan Etu pada kurun waktu 1978 hingga 1981, peran Etu dalam masyarakat pada masa itu, serta dampak ritual terhadap kehidupan bermasyarakat di Kampung Olaewa seiring dengan adanya modernisasi. Perbedaan penelitan milik Kalvaristo dengan penelitian ini terletak pada variabel penelitian dan lokasi penelitian. Penelitian ini berfokus pada representasi maskulinitas pada pelaksanaan ritual Etu yang berlokasi di Kampung Adat 
Tutubhada, Kecamatan Aesesa Selatan, Kabupaten Nagekeo NTT. Sementara itu, persamaan penelitian ini dengan penelitian terdahulu terletak pada objek penelitian yaitu rangkaian ritual Etu serta metode penelitian.

Penelitian lain mengenai Etu ditulis oleh Silvester Teda Sada selaku sekretaris Dinas Pariwisata Kabupaten Nagekeo pada tahun 2019. Silvester Teda Sada (2019) menjelaskan mengenai proses dan perlengkapan Etu di Kampung Nataia Kecamatan Aesesa, sementara artikel ini menjelaskan mengenai proses dan perlengkapan Etu di Kampung Adat Tutubhada Kecamatan Aesesa Selatan.

\section{B. METODE PENELITIAN}

Metode yang digunakan dalam penelitian ini adalah metode penelitian kualitatif deskriptif. Pada penelitian ini peneliti mendeskripsikan atau memaparkan hasilhasil wawancara mendalam terhadap subjek penelitian sebagaimana adanya sesuai dengan situasi dan kondisi ketika penelitian. Tujuan dari metode ini adalah untuk memahami secara luas dan mendalam terhadap suatu masalah secara detail pada suatu permasalahan yang sedang dikaji.

Pengumpulan data dimulai dengan studi pustaka yang dilakukan sebelum dan sesudah penelitian lapangan berlangsung. Studi pustaka ini dimaksudkan untuk mendapatkan data sekunder baik sebelum menuju ke lokasi penelitian maupun saat penyusunan laporan (Angelita, Sugiantari, Khinari, dan Manurung, 2018). Saat di lokasi, pengamatan atau observasi dilakukan untuk memperoleh data terkini terkait Etu. Kemudian, wawancara dilakukan untuk memperoleh informasi secara langsung guna menjelaskan suatu hal atau situasi dan kondisi tertentu, (Arifin, 2011). Narasumber dari wawancara yang dilakukan meliputi tokoh masyarakat, pemerintah desa, masyarakat dan pihak-pihak yang terlibat dalam Etu juga dilakukan untuk memperoleh data primer. Pencarian data tersebut didukung dengan studi dokumentasi sebagai penguat perolehan data baik saat wawancara maupun observasi. Analisis data yang digunakan yaitu deskriptif kualitatif dengan cara interpretatif data yang berarti merangkum, memilah dan menguraikan segala informasi yang diperoleh selama di lapangan sesuai dengan rumusan dan tujuan penelitian.

Lokasi penelitian ini dilaksanakan di Kampung Adat Tutubhada (Dusun Tutubhada), Desa Rendu Tutubhada Kecamatan Aesesa Selatan Kabupaten Nagekeo Pulau Flores Provinsi Nusa Tenggara Timur dengan titik koordinat $8^{\mathrm{O}}$ $37^{\prime} 36,6^{\prime \prime} \mathrm{S}$ dan $121^{\circ} 13$ '38,3" E. Peta lokasi penelitian dapat dilihat pada gambar 1 di bawah ini.
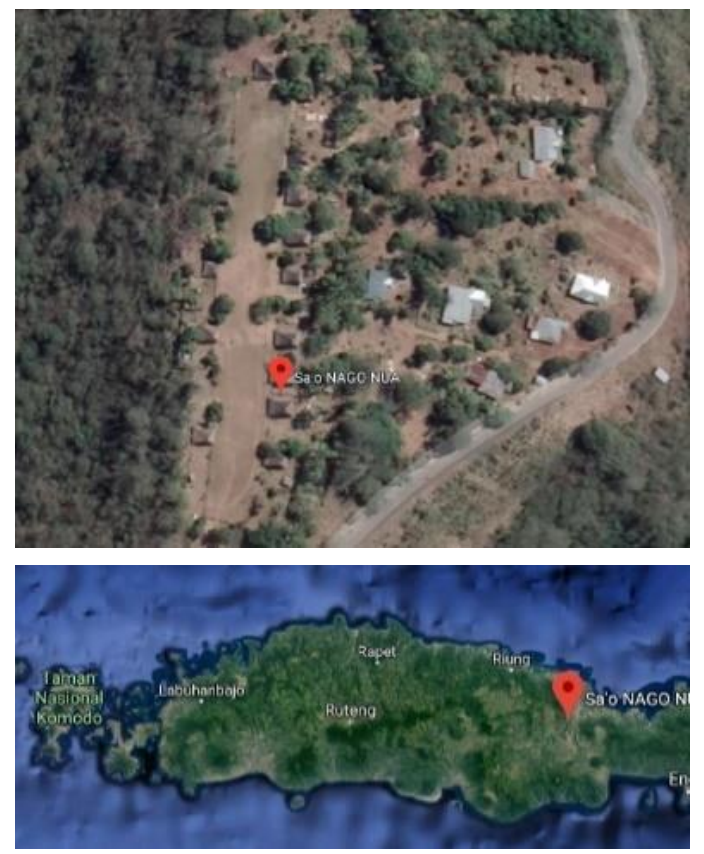

Gambar 1. Lokasi Penelitian Sumber: Google Maps, 2019. 


\section{HASIL DAN BAHASAN \\ 1. Gambaran Umum Desa Rendu Tutubhada}

Desa Rendu Tutubhada terletak di Kecamatan Aesesa Selatan, Kabupaten Nagekeo, Provinsi Nusa Tenggara Timur. Berdasarkan Peraturan Menteri Dalam Negeri Nomor 12 Tahun 2007 Tanggal 12 Maret 2007 mengenai Daftar Isian Potensi Desa dan Kelurahan, Desa Rendu Tutubhada berbatasan langsung dengan Langedhawe di sebelah utara, dan Tengatiba, Rendu Teno, serta Wajomara di sebelah selatan. Sebelah timur Desa Rendu Tutubhada berbatasan langsung dengan Ngegedhawe dan Wajomara, serta Rendu Teno dan Langedhawe di sebelah barat. Desa Rendu Tutubhada memiliki empat dusun yang meliputi Dusun Tutubhada, Tasikapa, Paupada, dan Denanunu (BPS Kabupaten Nagekeo, 2018).

\section{Kondisi Geografis Desa Rendu Tutubhada}

Secara topografi, bentang wilayah yang dimiliki oleh Desa Rendu Tutubhada yaitu dataran tinggi. Jarak Desa Rendu Tutubhada dengan Kota Mbay yang merupakan Ibukota Kabupaten Nagekeo yaitu \pm 10 kilometer. Perjalanan tersebut dapat ditempuh menggunakan kendaraan bermotor baik sepeda motor maupun mobil dengan aksesbilitas lancar dan mudah.

Desa Rendu Tutubhada memiliki total luas wilayah sebesar 513 ha dengan 78 ha dipergunakan sebagai permukiman, 100 ha untuk perkebunan yang rata-rata ditanami jagung, 40 ha untuk pekarangan, 10 ha merupakan lahan kritis, 3 ha untuk sarana dan prasarana, kuburan 1 ha dan perkantoran 1 ha, serta 280 ha sisanya merupakan lahan terlantar. Luas wilayah yang ditanami oleh jagung menghasilkan 70 ton di tiap hektarnya sekali panen. Hasil panen tersebut merupakan pencapaian yang didapat oleh masyarakat Rendu, sehingga melakukan ritual Gua Meze pada Juni-Juli. Menurut BPS (2016), Kecamatan Aesesa Selatan memiliki curah hujan 1207 $\mathrm{mm}$ yang memiliki tingkat kelembapan sedang dengan 62 hari hujan per tahunnya. (BPS Kabupaten Nagekeo, 2018).

\section{Data Kependudukan dan Mata Pencaharian Masyarakat Desa Rendu Tutubhada}

Desa Rendu Tutubhada terdiri atas $161 \mathrm{KK}$ dengan 401 orang laki-laki dan 421 orang perempuan. Pekerjaan masyarakat Desa Rendu Tutubhada yaitu mayoritas petani dengan 297 orang laki-laki dan 291 orang perempuan, sedangkan lainnya bekerja sebagai pegawai negeri sipil dan bidan. Keseluruhan penduduk Desa Rendu Tutubhada beragama Khatolik. Adapun jumlah masyarakat Desa Rendu Tutubhada berdasarkan usia dapat dilihat pada tabel 1 . Pembagian usia tersebut berdasarkan petarung ritual Etu yaitu Etu co'o dilakukan oleh anak yang memasuki sekolah taman kanak-kanak hingga SMP, sedangkan Etu meze dilakukan oleh anak SMA hingga usia yang tidak ditentukan, (Watu, wawancara, 18 Juli 2019).

Tabel 1. Usia masyarakat

Desa Rendu Tutubhada

\begin{tabular}{ccc}
\hline $\begin{array}{c}\text { Usia } \\
\text { (tahun) }\end{array}$ & Laki-Laki & Perempuan \\
\hline $0-5$ & 30 & 32 \\
\hline $6-12$ & 43 & 41 \\
\hline $13-15$ & 19 & 22 \\
\hline $16-18$ & 24 & 18 \\
\hline $19-25$ & 24 & 24 \\
\hline $26-35$ & 53 & 55 \\
\hline $36-50$ & 69 & 88 \\
\hline$>50$ & 120 & 139 \\
\hline
\end{tabular}

Sumber: Isian profil Desa Rendu Tutubhada, 2018.

\section{Temuan Penelitian}

Pada tahun 2019 Ritual Etu dilaksanakan di Bulan Juli dan peneliti dapat memberikan informasi mengenai rangkaian Etu, pelaku Etu yang terlibat, perlengkapan yang digunakan saat Etu, aturan pada saat Etu berlangsung, dan eksistensi Etu yang masih bertahan hingga kini. 


\section{a. Rangkaian Etu}

Ritual Etu merupakan salah satu tahapan dari ritual Gua Meze atau ritual syukur panen. Sebelum Ritual Etu dilaksanakan, terdapat beberapa ritual yang dilakukan untuk menyambut pagelaran tinju tradisional ini yang meliputi:

\section{1) Maki}

Ritual Maki biasa dilaksanakan pada malam hari yang diawali dengan berkumpulnya kaum laki-laku di tengah lapangan Kampung Adat Tutubhada yang kemudian bersama-sama menuju bagian hulu atau sebelah selatan kampung adat melalui wesa.

Wesa yaitu dua kayu sebagai pintu gerbang masuk Kampung Adat Tutubhada. Kaum laki-laki berjalan menuju wesa diikuti dengan nyanyian yang bernama "Diyo".

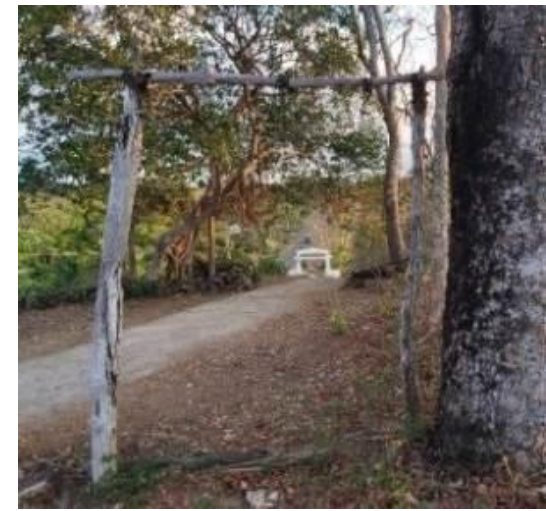

Gambar 2. Wesa

Sumber : Dokumentasi penulis, 2019.

Ritual dilanjutkan oleh para tetua adat yang menanyakan siapa saja bagian keluarga yang tidak ikut dalam kegiatan ritual Gua Meze. Orang yang tidak mengikuti ritual tersebut akan mendapatkan makian dari siapa saja yang hadir dalam kegiatan tersebut.

\section{2) Gedho Peko/Peko}

Ritual Gedho Peko merupakan kegiatan menumbuk padi. Ritual Gedho Peko dilakukan di dua tempat dengan membagi masyarakat Kampung adat Tutubhada menjadi dua kelompok yang dianggap sebagai hulu dan hilir kampung adat, (Zakarias Isa Laja, wawancara, 13 Juli 2019). Pembagian kelompok bergantung pada letak rumah adat. Bagian hulu atau selatan akan mengikuti kelompok di rumah Opa Zakarias, sementara rumah adat yang berada di bagian hilir atau utara mengikuti ritual di rumah Opa Alo.

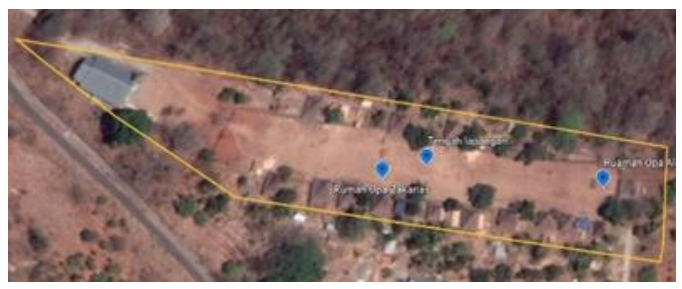

Gambar 3. Denah Kampung Adat Tutubhada Sumber: Google earth project, 2020.

Ritual ini dilakukan oleh kaum laki-laki. Kaum laki-laki yang menumbuk padi tidak memiliki syarat khusus, siapa saja boleh mengikuti Gedho Peko ini. Padi yang ditumbuk merupakan padi yang digunakan saat ritual pembuka dari Gua Meze. Padi yang telah ditumbuk kemudian ditapis dengan dibantu kaum wanita.

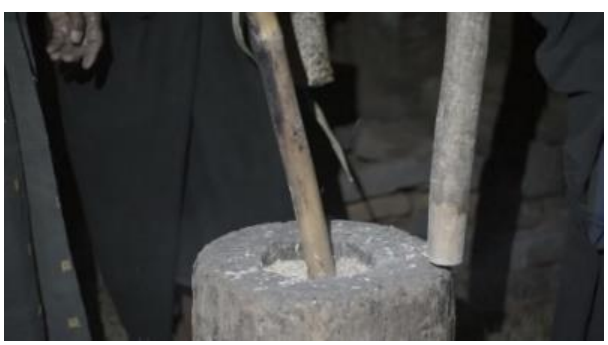

Gambar 4. Menumbuk Padi Sumber: Dokumentasi penulis, 2019.

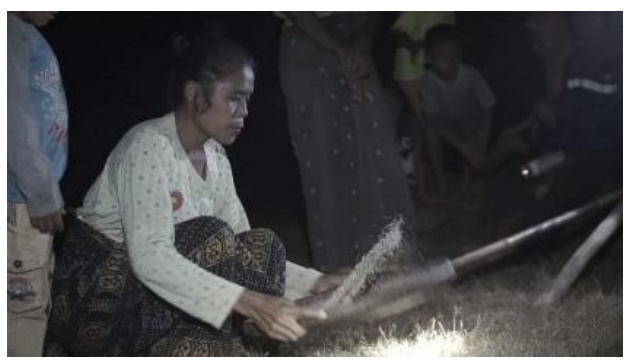

Gambar 5. Menapis Padi

Sumber: Dokumentasi penulis, 2019. 
Ritual Gedho Peko tidak dipimpin oleh tetua adat, kegiatan langsung dilanjutkan untuk menyiapkan beras guna dimasak di ritual selanjutnya.

\section{3) Naka api}

Ritual Naka Api atau curi api dilakukan oleh salah satu perwakilan anak laki-laki dari masing-masing kelompok untuk mengambil api. Ritual diawali dengan dibawa turunnya bara api dari rumah Opa Zakarias dan Opa Alo, kemudian dilanjutkan oleh perwakilan kelompok hilir yang pergi menuju kelompok hulu untuk mengambil kayu yang berisi api untuk dibawa ke rumah adatnya dengan berlari. Saat perwakilan anak dari kelompok hilir berlari membawa api, perwakilan anak dari kelompok hulu mengikuti untuk menangkap atau menggagalkan aksi curi api yang dilakukan kelompok hilir dan begitulah sebaliknya.

Jika api yang berhasil dicuri di tengah perjalanan, maka menandakan kelompok tersebut akan mengeluarkan banyak darah saat Etu berlangsung, (Zakarias Isa Laja, wawancara, 13 Juli 2019). Dalam ritual ini, perwakilan dari masing-masing kelompok bertugas untuk menjaga api yang dibawanya dan berusaha merebut api milik kelompok lawan.

\section{4) Pedhe Pene}

Ritual Pedhe Pene merupakan kegiatan memasak nasi di halaman depan rumah adat pada kelompok hulu dan hilir. Beras yang telah ditapis akan dimasukkan ke dalam periuk kecil dan dimasak menggunakan kayu bakar dari masingmasing rumah perwakilan kelompok tersebut. Ritual Pedhe Pene dilakukan dengan teliti dan hati-hati agar air tidak tumpah dari periuk nasi, karena jika air meluap menandakan kelompok tersebut akan banyak mengeluarkan darah saat Etu berlangsung.

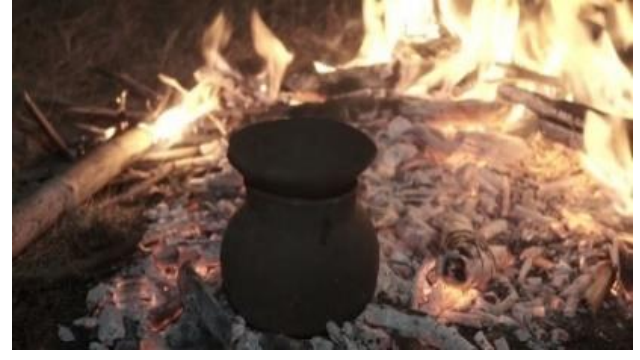

Gambar 6. Memasak Nasi

Sumber: Dokumentasi penulis, 2019.

Nasi yang telah masak kemudian ditutup rapat, disimpan, dan dijaga oleh salah satu tetua rumah adat dari masingmasing kelompok. Nasi di dalam periuk ini akan diberikan kepada anak laki-laki yang akan mengikuti ritual Etu Co'o keesokan harinya, (Zakarias Isa Laja, wawancara, 13 Juli 2019).

\section{5) Sagu A/u}

Sagu Alu adalah sebuah tarian yang menggunakan media bambu. Tarian ini menjadi salah satu pertanda dari banyaknya darah yang keluar saat Etu berlangsung.

Apabila semakin banyak kaki penari yang terjepit oleh bambu, maka semakin banyak darah yang akan keluar. Penari tidak boleh terjatuh saat menari di atas bambu, jika terjatuh penari harus melakukan upacara pemulihan bagi dirinya setelah kegiatan tersebut dilaksanakan. Nama penari Sagu Alu yaitu "Jai Sagu Alu" dan bagi pemegang atau pemain bambunya disebut "Dhego". Tidak ada kriteria khusus untuk menjadi Jai Sagu Alu maupun Dhego, semua masyarakat Kampung Adat Tutubhada dapat melakukan tarian ini. Menarikan Sagu Alu membutuhkan kelincahan para penari. Terdapat irama khusus untuk memainkan bambu Sagu Alu, yang iramanya itu disesuaikan dengan gerakan kaki para penari. 


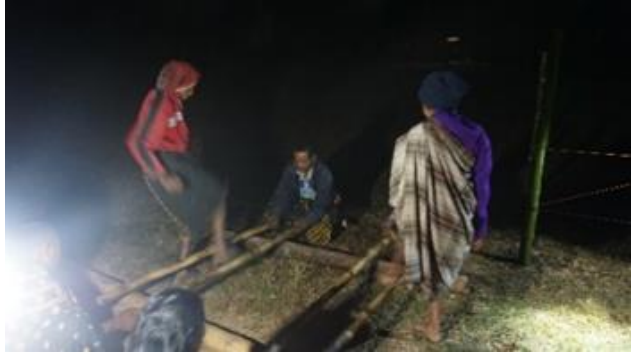

Gambar 7. Tarian Sagu Alu

Sumber: Dokumentasi penulis, 2019.

Tarian ini dilakukan hanya di satu tempat sebagai pertanda semua lingkaran kampung adat dari hulu dan hilir akan bermuara di tempat itu. Bambu yang digunakan untuk Sagu Alu merupakan bambu khusus yang disimpan di rumah Opa Zakarias (salah satu rumah tetua adat) yang akan diganti hanya ketika bambu tersebut sudah rusak. Sagu Alu menjadi pertanda bahwa Etu akan segera dilaksanakan dan juga menjadi tanda untuk tarian lainnya dan gong sudah dapat dimainkan. Tarian Sagu Alu dimulai dari pukul 05.00 WITA dan berakhir sampai matahari terbit, (Ngada, wawancara, 13 Juli 2020).

\section{6) Lo Pene}

Ritual Lo Pene adalah kegiatan menurunkan periuk nasi yang dilakukan sore hari sekitar pukul 15.00 WITA. Periuk nasi yang telah diturunkan akan diambil nasinya sedikit dan dikepalkan oleh salah satu tetua adat dari masing-masing kelompok kemudian dilemparkan ke arah kelompok lawan.

Pelemparan nasi tersebut diikuti dengan ucapan "Boka woka lau" yang artinya "sekalipun kau berdarah, kau akan selamat dan sembuh".
Nasi di periuk tersebut dibagikan ke anak laki-laki di masing-masing kelompok dengan cara diambilkan oleh perwakilan tetua masing-masing kelompok kemudian diletakkan di wadah kecil. Nasi yang telah diletakkan di wadah kecil kemudian dimakan oleh anak laki-laki di kelompok tersebut. Kegiatan makan nasi ini bertujuan untuk membuat anak laki-laki kuat pada saat tinju tersebut. Kegiatan tersebut dilakukan di dalam arena tinju yaitu di lapangan terbuka dan dibagi menjadi dua tempat yaitu hulu dan hilir. Tidak ada pembagian khusus bagi anak-anak untuk memakan nasi tersebut (Seda, wawancara, 19 Juli 2019).

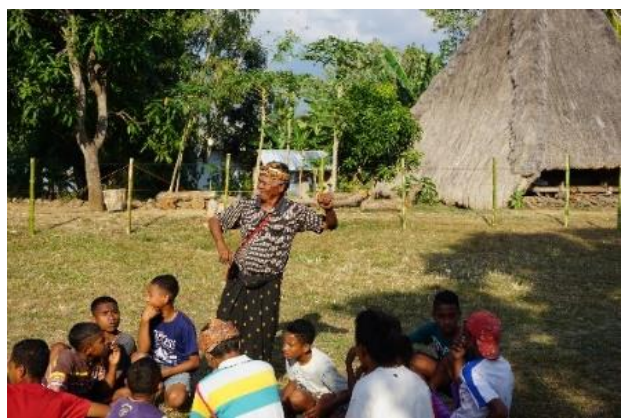

Gambar 8. Melemparkan kepalan nasi.

Sumber: Dokumentasi penulis, 2019.

\section{7) Etu}

Etu yang merupakan tinju tradisional ini dilakukan oleh kaum laki-laki baik anakanak (Etu Co'o) maupun dewasa (Etu Meze). Saat Etu berlangsung, petarung akan saling baku hantam di dalam arena pertarungan yang terletak di tengah lapangan Kampung Adat Tutubhada. Etu dilaksanakan di berbagai daerah di Kabupaten Nagekeo dan Kabupaten Ngada dengan perbedaan yang terletak pada alat yang digunakan maupun istilahnya. Salah satu daerah yang mengadakan Etu yaitu Kampung adat Tutubhada.

Etu di Kampung adat Tutubhada memiliki persamaan dengan Etu di Kampung Rendu Ola Desa Rendu Tutubhada karena merupakan satu suku yang sama yaitu Suku Rendu. Kampung 
adat Tutubhada menjadi anak kampung atau hilir dari suku Rendu, sementara induknya berada di Kampung Rendu Ola yang menjadi hulu suku. Persamaan Etu pada kedua kampung tersebut meliputi penyebutan nama Etu, pelaku Etu, peralatan Etu, dan aturan Etu. Perbedaannya hanya terletak pada waktu pelaksanaan yang berbeda satu hari dan lokasi pelaksanaan yang berada pada kampung masing-masing tersebut, (Alosius Lepa, wawancara, 13 Juli 2019).

\section{b. Pelaku Etu}

Pelaku Etu merupakan orang-orang yang terlibat dalam pelaksanaan Etu yang meliputi petarung, seka, sike, dan pai.

\section{1) Petarung}

Seperti pertarungan tinju pada umumnya, Etu juga melibatkan dua laki-laki untuk bertarung dalam satu arena. Petarung Etu terbagi menjadi dua macam yang dibedakan berdasarkan usia petarung yaitu:

\section{a) Etu Co'o}

Etu co'o merupakan sebuah ritual tinju dimana petarung dari tinju tersebut merupakan sepasang anak-anak. Etu co'o dilakukan setelah Lo Pene atau sehari sebelum Etu Meze dilakukan. Anak-anak yang menjadi petarung Etu Co'o merupakan anak berusia sekitar 5-15 tahun. Anak laki-laki yang akan bertarung tidak ditentukan darimana asalnya, namun dalam praktiknya petarung yang datang dari sebelah utara Desa Rendu Tutubhada akan menjadi petarung kelompok hilir dan yang datang dari sebelah selatan desa akan menjadi petarung kelompok hulu. Lawan petarung tidak memiliki aturan khusus hanya saja harus sepadan yang berarti kisaran umurnya tidak terlalu jauh dan ukuran fisik yang sama. Etu Co'o dilakukan dengan harapan anak-anak sudah terbiasa dengan Etu saat dewasa nanti, (Seda, wawancara, 20 Juli 2019).

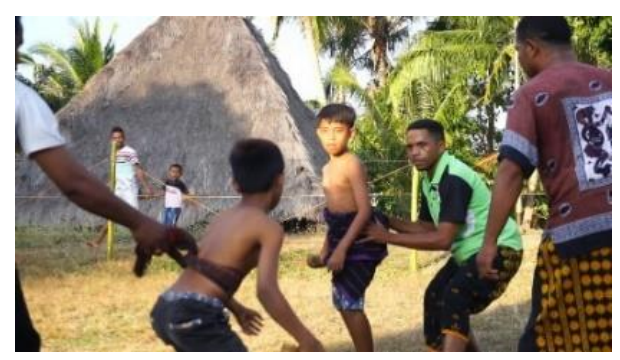

Gambar 9. Etu Co'o

Sumber: Dokumentasi penulis, 2019.

\section{b) Etu Meze}

Petarung Etu Meze merupakan sepasang laki-laki dewasa dengan kisaran umur 15 tahun ke atas atau anak laki-laki yang sudah memasuki jenjang sekolah menengah atas (SMA). Petarung Etu Meze juga tidak memiliki persyaratan khusus, asalkan lawan yang dihadapi memiliki kesamaan ukuran fisik, (Seda, wawancara, 20 Juli 2019).

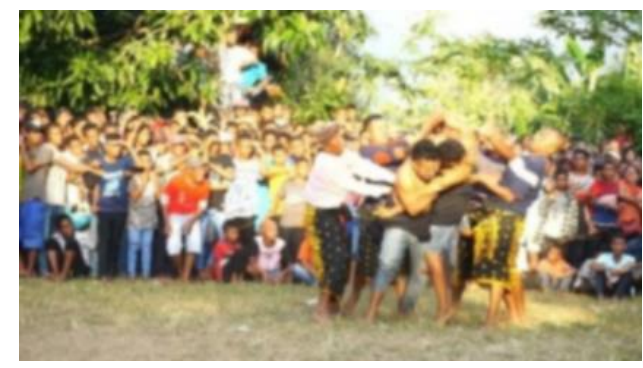

Gambar 10. laki-laki yang sedang bertarung. Sumber: Dokumentasi penulis, 2019.

\section{2) Seka}

Seka atau wasit merupakan penengah pada saat Etu berlangsung. Seka akan dipilih berdasarkan kesepakatan forum pada hari sebelum Etu berlangsung. Seseorang akan dipilih menjadi seka karena dianggap mampu serta memiliki sifat adil dan sportif. Pemilihan seka tidak ditentukan berdasarkan latar belakang tertentu. Seka yang terpilih juga tidak ada upacara khusus yang dilakukan sesudah maupun sebelum Etu berlangsung.

Seorang seka harus melerai petarung ketika emosi salah satu atau kedua petarung

tidak terkontrol. Seka akan melerai saat petarung memeluk satu sama lain, salah 
satu petinju dalam bahaya, dan suasana dalam pertandingan sudah tidak kondusif. Apabila seorang seka tidak mampu bersikap adil dan menimbulkan kekacauan antarkedua pihak, seka tersebut harus langsung diganti dan dikenakan sanksi setelah ritual selesai. Sanksi adat tersebut berupa beras dan daging babi untuk diberikan kepada masyarakat Rendu untuk dimakan bersama. Saat pertandingan telah usai, seka bertugas untuk mendamaikan petarung.

\section{3) sike}

Sike merupakan seseorang yang memegang atau mengontrol petarung dengan cara memegang kain yang digunakan petarung (ngeu) dari belakang. Ngeu harus dipegang dari bawah agar pegangan kuat dan tidak mudah terlepas. Sike harus memahami teknik Etu, sehingga sike tidak menjadi penghalang atau membatasi gerak petarung. Seorang sike boleh mendorong petarung untuk mendukung serangan tinju ke lawan, dan tidak boleh menarik atau menahan petarung sehingga pergerakannya tidak leluasa. Sike boleh melepaskan kain petarung ketika arus dari petarung lawan sangat kuat dengan tujuan menyelamatkan diri atau menghindari serangan lawan. Sike harus mampu memberikan semangat kepada petarung baik dengan kata-kata maupun tarian. Sike dipilih berdasarkan kesepakatan forum dan tidak ada pantangan maupun upacara khusus sesudah dan sebelum Etu dilaksanakan, (Ngada, wawancara, 22 Juli 2019).

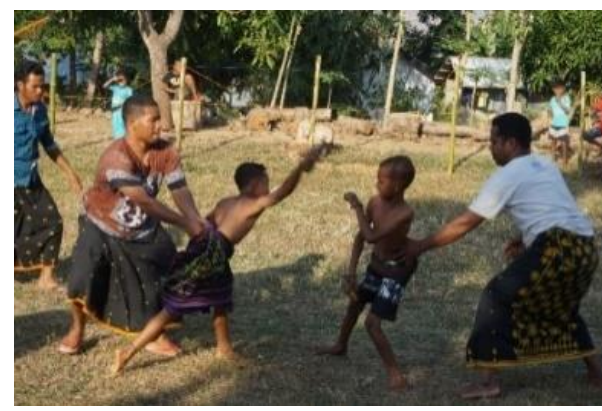

Gambar 11. Sike sedang menahan petarung. Sumber: Dokumentasi penulis, 2019.

\section{4) Pai}

Seseorang yang menjadi komunikator antara hulu dan hilir disebut dengan pai. Pai bertugas menjadi komunikator yang menghubungkan dua kelompok petarung untuk mencari lawan seimbang dengan persetujuan kedua petarung yang akan bertarung. Pai juga ditentukan oleh forum sebelum Etu berlangsung dan tidak ada pantangan atau upacara khusus sebelum maupun sesudah Etu berlangsung, (Ngada, wawancara, 22 Juli 2019).

\section{c. Perlengkapan Etu}

Etu memiliki berbagai macam perlengkapan yang digunakan oleh petarung maupun masyarakat Rendu untuk memberikan semangat saat pertarungan berlangsung. Perlengkapan tersebut meliputi:

\section{1) Kepo}

Kepo merupakan sarung tinju yang digunakan saat Etu. Masyarakat Desa Rendu Tutubhada biasa membuat kepo baru jika Etu akan dilaksanakan. Kepo terbuat dari beberapa bahan yaitu serabut kelapa (robanio), tulang lontar (tokokoli), dan kulit pohon (nuka) yang sudah dipintal untuk nantinya digunakan sebagai tali saat mengikat kepo, serta tali rafia sebagai pengikat tambahan. Cara pembuatannya yaitu dengan memilin kecil tulang lontar dan digumpal hingga sesuai dengan genggaman tangan laki-laki. Tulang lontar yang sudah digumpal, selanjutnya dibungkus dengan serabut kelapa hingga menutupi seluruh bagiannya dan hanya menyisakan rongga di bagian ujung tulang lontar. Rongga inilah yang nantinya akan digunakan untuk melukai lawan. Kepo yang sudah setengah jadi tersebut lalu diikat di bagian ujungnya dengan menggunakan tali rafia, serta nuka yang diikatkan pada bagian akhir dari kepo sebagai pengikat di tangan petarung yang akan melakukan tinju, (Ngada, wawancara, 22 Juli 2019). 


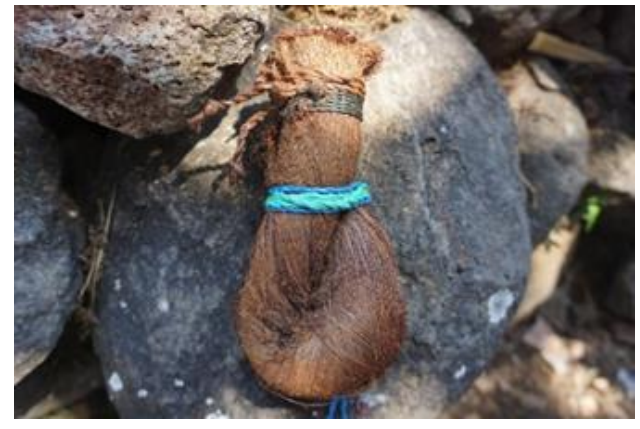

Gambar 12. Kepo

Sumber: Dokumentasi penulis, 2019.

\section{2) Sada Etu}

Sada Etu merupakan kain tradisional seperti sarung yang digunakan oleh pelaku Etu selama pertandingan berlangsung dan orang lain yang tidak menggunakan sada tidak diperolehkan masuk ke dalam arena Etu. Sada merupakan salah satu busana khas masyarakat Rendu.

Petarung menggunakan kain ini sebagai bawahan dan tidak memakai baju. Sada Etu yang digunakan tidak ada yang khusus, pelaku Etu dapat menggunakan kain yang dimilikinya masing-masing, (Ngada, wawancara, 21 Juli 2019).

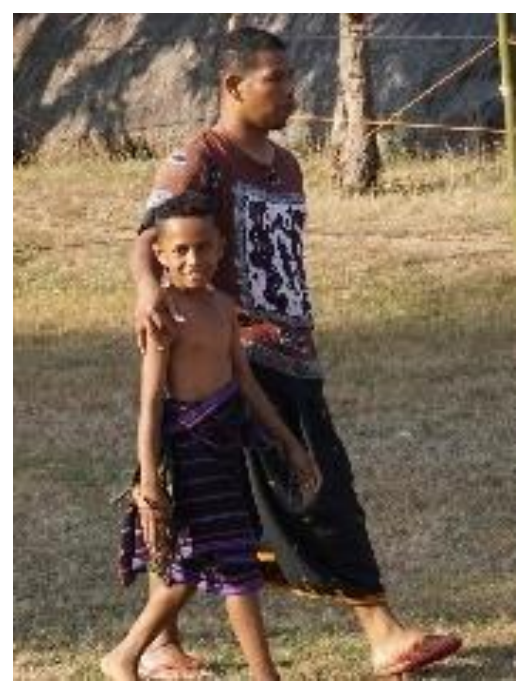

Gambar 13. Sada Etu

Sumber: Dokumentasi penulis, 2019.

\section{3) Ngeu}

Ngeu adalah selendang yang digunakan petarung saat melakukan Etu. Ngeu akan diikatkan di pinggang petarung setelah memakai sada. Ngeu tersebut akan dipegang oleh sike yang ada di arena, agar nantinya bisa ditarik jika ada petarung yang emosinya tidak terkendali, (Ngada, wawancara, 21 Juli 2019).

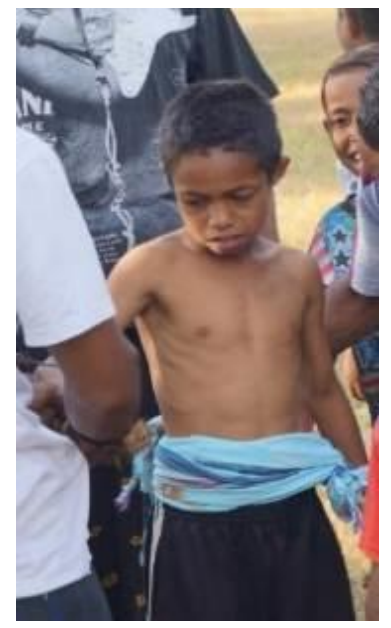

Gambar 14. Petarung menggunakan ngeu. Sumber: Dokumentasi penulis, 2019.

\section{4) Gong dan Kendang}

Saat Etu berlangsung, terdapat gong dan kendang yang digunakan untuk mengiringi kegiatan ritual. Gong dan kendang yang digunakan yaitu berupa 1 buah kendang dan 5 buah gong berukuran kecil. Jumlah gong tersebut tidak dapat ditambah maupun dikurangi karena bunyi yang ditimbulkan dari keenam alat musik tersebut sudah sesuai dengan nada yang diinginkan dan hal tersebut sudah berlangsung sejak dari nenek moyang di Desa Rendu Tutubhada, (Ngada, wawancara, 21 Juli 2019).

Gong dan kendang yang digunakan dalam kegiatan Etu berasal dari rumah Opa Zakarias. Gong dan kendang tersebut

bukan kendang asli yang diwariskan secara turun-temurun melainkan hanya kendang biasa yang selalu digunakan dalam setiap kegiatan yang ada di desa, sedangkan kendang asli disimpan di 
rumah Opa Alo, yaitu wakil ketua suku di Desa Rendu dan hanya boleh digunakan saat upacara pembedahan rumah adat dan dibutuhkan upacara khusus sebelum diturunkan dari rumah adat.

Pemukulan gong dan kendang tersebut tidak ada aturan, hal tersebut tergantung pada bakat seseorang yang memainkannya. Gong dan kendang ini biasa dimainkan saat petarung telah memasuki arena dan saat petarung telah memulai pertarungannya, gong akan berhenti dimainkan. Saat petarung sudah kembali berdamai, akan diikuti dengan teriakan "haiyayahaiyaya" dan barulah gong kendang kembali dibunyikan, (Ngada, wawancara, 21 Juli 2019).

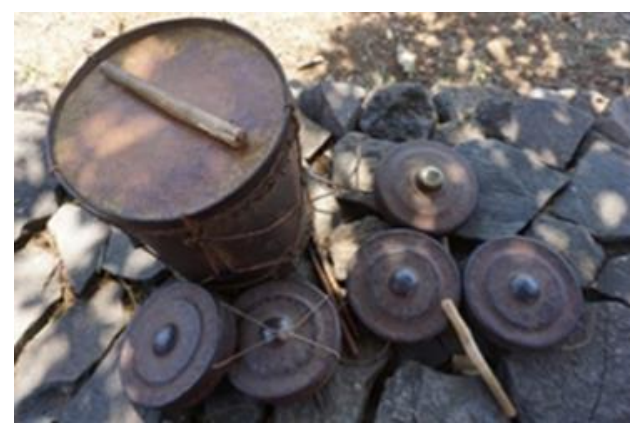

Gambar 15. Gong dan Kendang Sumber: Dokumentasi penulis, 2019.

\section{d. Aturan Etu}

Saat bertarung, petarung Etu hanya diperbolehkan menggunakan kedua tangan yang mana salah satu tangannya memukul dengan menggunakan kepo dan satu lagi berfungsi untuk menangkis serangan dari lawan. Petarung Etu dilarang menyerang lawan dengan menggunakan kaki dan memeluk lawan. Jika ronde pertama telah diselesaikan oleh seka, petarung dapat meminta ronde bertarung berikutnya dengan memberi isyarat kepada sike yang memegang mereka atau memberi isyarat langsung kepada seka. Pertarungan ini dilakukan bukan untuk mencari pemenang, sehingga Etu akan diakhiri oleh seka ketika salah satu dari petarung sudah menyerah atau mulai mengeluarkan darah. Petarung yang mengeluarkan darah tidak ditangani secara medis karena kepercayaan masyarakat bahwa luka yang ada akan sembuh dalam tiga hari. Darah yang keluar saat Etu dianggap sebagai ajakan bagi setiap generasi berikutnya untuk memahami dan mau belajar mengenai sikap kebersamaan, sikap konsisten, serta saling menghargai, (Ngada, wawancara, 22 Juli 2019).

\section{e. Eksistensi Etu di Masa Kini}

Etu di Kampung adat Tutubhada telah menjadi tradisi masyarakat Rendu sejak kurang lebih 150 tahun yang lalu apabila dilihat dari jumlah tanduk kerbau yang ada di dalam rumah adat. Menurut kepercayaan tokoh masyarakat, satu tanduk kerbau melambangkan 30 tahun usia rumah adat dan rumah adat tertua memiliki lima buah tanduk kerbau. Etu yang telah berusia 150 tahun masih dilaksanakan oleh masyarakat Rendu saat ini karena beberapa faktor, yang meliputi:

\section{1) Kepercayaan Terhadap Pantangan Nenek Moyang}

Salah satu unsur penting di dalam melestarikan nilai-nilai budaya dalam masyarakat adalah upacara-upacara yang berkaitan dengan kepercayaan dan religi yang mereka anut (Rusnandar, 2013). Di balik modernisasi akibat globalisasi, ritual Etu menjadi salah satu tradisi budaya yang masih kental dengan ketradisionalannya. Masyarakat Rendu yang tetap menghadirkan ritual Etu sebagai bentuk syukur panen menjadi salah satu contoh bahwa masih adanya kepercayaan terhadap pantangan nenek moyang yang jika tidak dilaksanakan maka roh-roh nenek moyang akan murka yang dapat menyebabkan gagal panen, (Ilwan, Dirman, dan Wardani, 2019). Selain itu, Orang yang berada di arena diusahakan agar tidak terjatuh karena dianggap ada hal buruk di dalam diri orang yang terjatuh tersebut. Kepercayaan masyarakat Rendu Tutubhada mengenai keberadaan nenek moyang masih sangat kental, sehingga Ritual Etu dapat terjaga hingga kini, (Alosius Lepa, wawancara, 14 
Juli 2020). Sesuai skema budaya masyarakat Tuhan, roh leluhur dan roh alam adalah sumber kekuatan spiritual dan moral utama yang sangat menentukan keberadaan, kebertahanan, dan keberlanjutan hidup masyarakat sebagai manusia dan masyarakat untuk kehidupan di dunia menuju kehidupan akhirat yang kekal dan abadi (Labur, 2019).

\section{2) Mata Pencaharian Masyarakat Rendu Sebagai Petani}

Menurut data kependudukan dan mata pencaharian masyarakat Desa Rendu Tutubhada, sekitar $70 \%$ masyarakatnya hidup dari sektor pertanian. Lahan yang dimilikipun tidak hanya di area Desa Rendu Tutubhada, namun juga tersebar hingga Kota Mbay. Hasil panen yang didapat setiap tahun menjadi persediaan pangan serta modal untuk dijual oleh para petani Rendu. Hal itulah yang menjadi salah satu faktor ritual syukur panen masih dilaksanakan hingga kini karena Gua Meze merupakan cara masyarakat Rendu untuk bersyukur atas hasil panen di musim sebelumnya dan memohon kesuburan dari nenek moyang untuk musim selanjutnya, (Watu, wawancara, 18 Juli 2020).

\section{3) Masih Adanya Pelaku Ritual}

Hingga kini, pelaku ritual yang merupakan tetua adat masih ada dan turut andil dalam pelaksanaan ritual. Tetua adat yang dimaksud adalah mereka yang menerima nilai-nilai mengenai Etu dari generasi sebelumnya dan paham mengenai segala hal yang berkaitan dengan Etu dimulai dari rangkaian, perlengkapan, nyanyian, serta aturannya. Tetua-tetua adat tersebut hingga saat ini mewariskan nilai-nilai mengenai Etu kepada generasi selanjutnya.

Tetua di setiap rumah adat Tutubhada akan mengajarkan kepada generasi selanjutnya dengan berlatih nyanyian, doa-doa, maupun memahami makna dari setiap tahapan ritual sehingga dapat memimpin beberapa kegiatan di ritual. Hal itu yang tetap menjaga nilainilai dan tatanan ritual, sehingga tidak banyak mengalami perubahan dari generasi ke generasi. Namun, untuk ritual-ritual yang dianggap sakral dan melibatkan komunikasi langsung dengan nenek moyang masih dilakukan oleh tetua adat, seperti ritual pembukaan Gua Meze.

\section{4) Adanya Pendidikan Sejak Dini}

Anak usia dini adalah sosok individu yang sedang menjalani suatu proses perkembangan dengan pesat serta memiliki karakteristik dan potensi yang harus dikembangkan dengan memberikan kesempatan pada anak untuk mengeksplorasi berbagai pengalaman yang disesuaikan dengan tahapan perkembangan anak sehingga pendidikan pada anak usia dini digunakan sebagai tempat untuk menstimulasi setiap perkembangan dan kebutuhan anak. Anak usia dini pada dasarnya sedang mengalami pertumbuhan dan perkembangan.

Pengenalan ritual Etu di Desa Rendu, Tutubhada sudah dilakukan pada anak usia dini, anak laki - laki yang masih berusia 5 tahun ke atas sudah diperbolehkan mengikuti pertandingan Etu, sedangkan anak perempuan meramaikan dengan menari pada saat ritual Etu berlangsung. Pembelajaran tersebut diterapkan dari pra ritual Etu hingga pasca ritual Etu. Anak-anak terlihat gembira dan bersemangat saat melaksanakan sejumlah rangkaian ritual Etu yang disimulasikan. Orang tua anak-anak Desa Rendu, Tutubhada mengatakan, kegiatan keagamaan seperti ritual Etu yang dilakukan sejak dini sangat bermanfaat dalam membantu membentuk karakter anak-anak mereka, (Seda, wawancara, 20 Juli 2019). Salah satu orang tua yang memiliki anak sebagai petarung di Etu Co'o mengatakan bahwa tidak takut ataupun khawatir saat melihat anaknya melakukan tinju saat ritual karena kepercayaan akan luka yang ada dapat sembuh dalam tiga hari tanpa bantuan medis. Selain itu, anak yang mengikuti Etu Co'o akan berlatih dan belajar berani serta 
ikut melestarikan budaya, wawancara, 22 Juli 2019).

\section{5) Adaptif}

Dalam perkembangannya, Etu mengalami beberapa perubahan dalam pelaksanaannya. Hal ini dilihat dari beberapa benda yang saat ini tidak banyak tersedia di alam, sehingga harus dicarikan penggantinya. Adaptif yang terjadi dalam pelaksanaan Etu yaitu:

\section{a) Sagu alu}

Penari dalam ritual sagu alu ini seharusnya dilakukan oleh anak-anak muda yang penuh energi, tetapi karena kurangnya antusias dan banyaknya anak yang takut dengan pamali maka mereka tidak ingin memainkan tarian tersebut. Hal ini membuat sagu alu hanya dilakukan oleh tetua adat di Kampung adat Tutubhada.

\section{b) Loka bue roga}

Loka bue roga merupakan salah satu kegiatan berbalas pantun yang dilakukan setelah Etu Meze. Loka bue roga yang dilakukan oleh kaum muda untuk mencari pasangan sudah tidak dilakukan di masa kini karena perkembangan teknologi yang pesat sehingga mencari jodoh melalui balas pantun tidak lagi memiliki esensi bagi kaum muda.

\section{c) Kepo}

Salah satu bahan pembuatan kepo yaitu tali yang terbuat dari kulit pohon, namun karena tali tersebut sudah jarang ditemukan dan terdapat bahan alternatif lain, maka untuk mengikat kepo tersebut diganti dengan tali rafia.

\section{6) Ketersediaan Lokasi}

Etu di Kampung Adat Tutubhada yang merupakan hilir kampung akan terus dilaksanakan di lapangan kampung adat karena apabila akan ke tempat lain tokoh masyarakat akan meminta persetujuan nenek moyang dengan bacaan-bacaan doa tertentu dan apabila dilakukan di tempat lain maka masyarakat Kampung adat
Tutubhada percaya akan terjadi petaka, (Laja, wawancara, 13 Juli 2019).

\section{7) Adanya Dukungan dari Pemerintah}

Ritual Etu menjadi salah satu daya tarik masyarakat luar untuk mengunjungi Desa Rendu Tutubhada. Selain dapat mempertahankan eksistensi Etu di masa kini, ritual ini juga memiliki potensi untuk menyejahterakan masyarakat Rendu. Potensi pengembangan daya tarik tersebut didukung oleh pemerintah Desa Rendu Tutubhada dengan bentuk pengadaan amenitas untuk menunjang aktivitas pariwisata baik dalam bentuk fasilitas pendukung seperti lahan parkir, rumah singgah, dan toilet. Dinas Kebudayaan dan Pariwisata Kabupaten Nagekeo juga telah mengadakan pelatihan pemandu wisata bagi masyarakat Desa Rendu Tutubhada untuk mendampingi wisatawan yang datang dan ingin mempelajari budaya di Kampung Adat Tutubhada. Ritual Etu yang telah masuk ke dalam daftar warisan tak benda pada tahun 2015 juga merupakan salah satu bentuk dukungan pemerintah untuk mempertahankan eksistensi Etu hingga kini.

\section{8) Atraktif}

Etu merupakan ritual yang menarik, sehingga dapat digunakan untuk menarik wisatawan ke Kampung Adat Tutubhada ini. Indonesia memiliki potensi yang besar dalam pengembangan pariwisata, karena selain memiliki alam yang indah juga aneka ragam budaya dan adat istiadat. Setiap dilaksanakannya Etu, Kampung Adat Tutubhada didatangi oleh pengunjung dari berbagai daerah di Pulau Flores. Namun, kedatangan pengunjung yang sangat tinggi belum dikelola dengan baik oleh masyarakat Rendu, sehingga potensi yang belum tergarap secara optimal. Hal itu mungkin dikarenakan alasan dana maupun sumber daya manusia yang belum siap (Rostiyati, 2013). Meskipun demikian, eksistensi Etu masih terjaga sampai sekarang karena mempunyai daya tarik yang meliputi motif tinju tradisional ini 
adalah murni bagian dari adat tanpa melihat darimana asal petarung, dilaksanakan satu tahun sekali di waktu tertentu, dan tidak dipungut biaya untuk menontonnya.

\section{Representasi Maskulinitas dalam Etu}

Ritual Gua Meze menjadi ritual tahunan bagi masyarakat Rendu sebagai tanda syukur atas hasil panen yang berhasil dilakukan. Dalam Ritual Gua Meze memiliki beberapa rangkaian ritual yang dilakukan dan ritual Etu menjadi salah satu ritual inti perayaannya. Ritual Etu dilaksanakan sebagai tanda sorak gembira masyarakat yang diwujudkan dengan pertarungan di arena tinju. Namun dalam pelaksanaannya, yang dapat terlibat dalam seluruh rangkaian ritual Etu hanyalah kaum laki-laki karena dianggap sebagai makhluk yang keras dan berani (Alosius Lepa, wawancara, 13 Juli 2019). Dari seluruh rangkaian Ritual Etu yang hanya dapat melibatkan kaum laki-laki tersebut menunjukkan adanya representasi maskulinitas melalui ritual ini.

Pada Ritual maki, wanita tidak dapat mengikuti ritual ini karena adanya pamali yaitu tentang kepercayaan nenek moyang bahwa kaum wanita merupakan kaum yang terkenal halus kata dan perilaku, sehingga tidak sesuai dengan Ritual maki yang harus mengeluarkan kata-kata kasar. Dalam ritual ini hanya dapat diikuti oleh kaum laki-laki karena laki-laki memiliki watak kasar dan keras, (Ngada, wawancara, 17 Juli 2019). Representasi maskulinitas pada kaum laki-laki terlihat dalam pengambilan peran untuk meluapkan emosi kepada penduduk kampung adat yang tidak megikuti ritual sebelumnya. Hal tersebut dapat menjelaskan bahwa laki-laki memiliki kemampuan mengontrol dan ucapannya mampu memengaruhi dalam pengambilan keputusan. Maskulinitas kembali dipresentasikan dalam Ritual gedho peko. Kegiatan menumbuk padi ini dilakukan oleh laki-laki yang menunjukkan kuasa maskulinitasnya dalam mengambil pekerjaan yang berat. Dalam ritual ini, karakter laki-laki yang berjiwa keras dan kuat dihadirkan melalui kegiatan menumbuk padi yang tidak boleh diambil alih oleh kaum perempuan. Kaum perempuan hanya dapat membantu pada saat menapis padi. Pada Ritual naka api juga menampakkan maskulinitas laki-laki yaitu peran tanggungjawab dalam menjaga api supaya tidak dicuri menandakan bahwa laki-laki diberikan kepercayaan untuk mencapai tujuan yang telah diamanahkan.

Ritual Etu yang dilakukan bukan hanya pertarungan yang digunakan sebagai pelampiasan amarah dengan saling memukul, tetapi memiliki makna kebersamaan dan saling menghargai yang tercermin pada pelaku Etu. Makna kebersamaan dan saling menghargai dilihat dari seluruh rangkaian yang direncanakan dan diwujudkan melalui musyawarah untuk mufakat antarkaum laki-laki sebagai kepala rumah tangga, sehingga diharapkan dapat memberikan keputusan-keputusan yang mewakili seluruh keluarga di Kampung Adat Tutubhada. Musyawarah tersebut dilakukan untuk menetapkan waktu serta menentukan pelaku-pelaku Etu yang akan terlibat.

Etu yang dilakukan oleh laki-laki menunjukkan kewibawaan dan kekuatan yang diwariskan oleh nenek moyang saat perang, sehingga hari ini Etu menjadi bukti kewibawaan dan harga diri laki-laki (Mammilianus, 2010). Meskipun makna tersebut dipegang erat oleh masyarakat Rendu, tidak ada paksaan bagi kaum lakilaki untuk menjadi pelaku Etu baik petarung maupun peran pendukung Etu. Hal tersebut juga menjadi wujud dari makna saling menghargai yang dipegang erat oleh masyarakat Rendu, (Ngada, wawancara, 22 Juli 2019).

Tinju tradisional yang dilakukan oleh dua orang laki-laki yang saling hantam ini menunjukkan bahwa terdapat penanda maskulinitas seperti kekuatan, ketabahan, pengendalian diri, kepuasan diri, dan kesetiakawanan di dalamnya. Kekuatan ditunjukkan dengan aksi tinju atau saling memukul satu sama lain. 
Ketabahan ditunjukkan dengan kemampuan petarung saat menerima kekalahan dalam pertarungan. Pengendalian diri dapat terlihat dari kemampuan petarung mengontrol emosi agar Etu atau tinju tidak melewati batas dan melenceng dari maksud ritual. Kepuasan diri ditunjukkan dengan gerakan meninju sekuat tenga dan meluapkan emosi, tetapi masih di bawah kendali. Kemudian kesetiakawanan laki-laki dapat dilihat pada aksi berpelukan seusai tinju dilaksanakan yang menandakan bahwa persahabatan masih tetap terjalin dan pertarungan tidak akan terjadi di luar ritual Etu.

Ritual Etu tidak memperbolehkan wanita terlibat langsung dan menjadi pelaku Etu karena dianggap sebagai sosok yang suci, berwatak halus, dan memelihara. Bahkan, kaum wanita tidak diperbolehkan memasuki arena tinju dan melintasi jalur keluar masuknya petarung menuju arena. Hal ini dipercayai dapat mengakibatkan banyaknya pertumpahan darah yang terjadi saat Etu berlangsung dan memperparah luka yang diderita petarung. Meskipun darah yang keluar dari petarung merupakan lambang keberkahan yang melimpah selama satu tahun, tetapi petarung tidak akan melanjutkan pertarungan jika salah satu dari petarung sudah terluka. Kepercayaan ini masih dipegang oleh masyarakat Rendu sehingga kaum wanita hanya dapat berdiam di pinggir arena sambil bernyanyi dan menarikan lagu “diyo" untuk meramaikan dan memberi semangat kepada petarung.

\section{PENUTUP}

Dari beberapa pembahasan mengenai Etu di Kampung Adat Tutubhada di atas dapat ditarik simpulan sebagai berikut:

- Kegiatan yang dilakukan sebelum ritual Etu dilangsungkan meliputi ritual maki, gedho peko, naka api, pedhe pene, sagu alu, dan lo pene.

- Pelaku Etu meliputi petarung, sike, seka, dan pai.

- Perlengkapan Etu yang digunakan meliputi kepo, sada Etu, ngeu, serta gong dan kendang.

- Aturan Etu meliputi tindakan yang boleh dan tidak boleh dilakukan oleh petarung, serta batasan pertandingan yang dapat dilakukan.

- Eksistensi Etu di masa kini tetap terjaga karena adanya beberapa faktor yang meliputi kepercayaan terhadap pantangan nenek moyang, mata pencaharian masyarakat Rendu sebagai petani, masih adanya pelaku ritual, adanya pendidikan sejak dini, adaptif, adanya dukungan dari pemerintah, dan atraktif.

- Etu hanya dapat dilakukan oleh kaum laki-laki sebagai sosok yang keras dan berani, sehingga maskulinitas kaum laki-laki yang dipresentasikan kembali dalam Etu dalam bentuk kekuatan, ketabahan, pengendalian diri, kepuasan diri, dan kesetiakawanan. Kaum wanita tidak diperbolehkan terlibat dalam Ritual Etu karena dianggap sebagai kaum yang suci dan memelihara, sehingga tidak sesuai dengan karakteristik pertarungan yang bersifat keras dan mengeluarkan darah.

- Melalui rangkaian Ritual Etu yang dilaksanakan, kaum wanita hanya berperan sebagai pendukung dari kegiatan yang dilakukan oleh kaum laki-laki dan kaum laki-laki menjadi pelaku utama dari seluruh rangaian Ritual Etu.

Saran yang dapat peneliti sampaikan kepada pemerintah berkaitan dengan Etu di Kampung Adat Tutubhada ini yaitu meningkatkan upaya pelestarian dengan memperkenalkan Etu kepada masyarakat luas. Salah satu cara yang bisa disarankan yaitu dengan menjadikan Kampung Adat Tutubhada menjadi desa wisata budaya yang didukung dengan berbagai kegiatan pameran, event, pertunjukan dan juga publikasi yang baik kepada masyarakat luas. Namun tidak hanya itu, pelatihanpelatihan sumber daya manusia juga sangat diperlukan sehingga masyarakat siap menerima kedatangan tamu untuk 
menyaksikan Etu sebagai ritual kebanggaan masyarakat Kampung Adat Tutubhada.

Saran untuk masyarakat setempat adalah masyarakat harus lebih meningkatkan dan mempererat kerukunan, gotong-royong, dan persatuan sehingga Etu bisa berkembang. Kesadaran akan pentingnya pendidikan harus lebih ditanamkan, sehingga masyarakat lokal mendapatkan ilmu pengetahuan dan informasi yang luas dan menyadari penuh akan tradisi yang dimilikinya harus dijaga dan dilestarikan. Masyarakat juga diharapkan lebih kreatif dan inovatif dalam mengembangkan Etu yang menjadi salah satu daya tarik wisatanya, sehingga dapat meningkatkan kunjungan wisatawan.

Kelompok sadar wisata (pokdarwis) Desa Rendu Tutubhada harus lebih meningkatkan pelayanan terhadap wisatawan sehingga dapat mencapai standar nasional maupun internasional dan lebih berkonsentrasi dalam mempromosikan potensi wisata. Saran untuk tokoh adat agar mewariskan ilmu pengetahuan mereka mengenai Etu dan tradisi di Kampung Adat Tutubhada kepada generasi muda untuk melanjutkan tradisi di masa yang akan datang.

\section{UCAPAN TERIMA KASIH}

Terselesaikannya penelitian ini tidak lepas dari dukungan dan doa dari berbagai pihak, sehingga dengan segenap hati penulis ingin mengucapkan terima kasih kepada:

- Desa Rendu Tutubhada, tokoh masyarakat serta masyarakat Kampung Adat Tutubhada atas informasi, fasilitas, dan dukungannya.

- Sponsor Udayana Scientific Excursion (USE) 2019 meliputi BPD, Serenity, dan BPR Lestari.

- Seluruh anggota Mapala "Wanaprastha Dharma" Universitas Udayana yang telah memberikan dukungan, sehingga USE 2019 dapat terlaksana dengan baik.

\section{DAFTAR SUMBER}

Angelita, C., Sugiantari, N. M. Y., Khinari, A. S. P., dan Manurung, R. F. (2018). Laporan penelitian: Udayana Scientific Excursion Divisi Studi Budaya pada Bangunan Uma Lengge Desa Maria Kabupaten Bima NTB. Denpasar: Mapala Wanaprastha Dharma Universitas Udayana.

Arifin, Z. (2011). Penelitian Pendidikan. Bandung: PT Remaja Rosdakarya.

BPS Kabupaten Nagekeo (2018). Kabupaten Nagekeo Dalam Angka 2018. Nagekeo: Badan Pusat Statistik Kabupaten Nagekeo.

Budiman, H. G. (2013). Makna dan Nilai Budaya Tapis Inuh pada Masyarakat Pesisir di Lampung Selatan. Patanjala, 5 (3), 522

Danandjaja, J. (2002). Folklor Indonesia. Jakarta: Grafiti.

Duka, F. (22 Juli 2019). Wawancara.

Ilwan, I., \& Wardani, A. K. (2019). Ritual Mewuhiha Limano Bhisa dalam Menyambut Pesta Panen pada Masyarakat Desa Morindino Kecamatan Kambowa Kabupaten Buton Utara. Jurnal Kelisanan Sastra dan Budaya, 2 (2), 37-38.

Kalvaristo, K. Y. (2007). Etu Masyarakat Kampung Olaewa Flores 1978 - 1981. Ilmu Sejarah Fakultas Sastra Universitas Sanata Dharma Yogyakarta.

Khinari, A. S. P., Dewi, A. A. A. I. S., Lubis, D. N., Juliyanti, N. P. I., Sugiantari, N. M. Y., Marlina, N. K. A. (2019). Laporan penelitian: Udayana Scientific Excursion Divisi Studi Budaya mengenai Ritual Etu di Kampung Adat Tutubhada Desa Rendu Tutubhada Kecamatan Aesesa Selatan Kabupaten Nagekeo Provinsi Nusa Tenggara Timur. Denpasar: Mapala "Wanaprastha Dharma" Universitas Udayana.

Koentjaraningrat. (2009). Pengantar Ilmu Antropologi. Jakarta: Rineka Cipta.

Labur, B. H. K. (2019). Nilai-Nilai Religius dalam Ritual Tudak Penti di Kampung Teber-Manggarai Timur (Telaah Atas Upacara Syukuran Hasil Panen dalam 
Etnis Budaya Manggarai). Diploma thesis Universiras Katolik Widya Mandira.

Laja, Z. I. (13 Juli 2019). Wawancara.

Lepa, A. (13 Juli 2019). Wawancara.

Lepa, A. (14 Juli 2019). Wawancara.

Mammilianus, S. (2010). Tinju Adat Nagekeo: Kewibawaan dan Harga Diri. Diakses 13 Maret 2021 dari tribunnews.com/tribunners/2010/08/02/ke wibawaan-dan-harga-diri

Ngada, B. (13 Juli 2019). Wawancara.

Ngada, B. (17 Juli 2019). Wawancara.

Ngada, B. (21 Juli 2019). Wawancara.

Ngada, B. (22 Juli 2019). Wawancara.

Republik Indonesia. (2003). Undang Undang No. 20 Tahun 2003 tentang Sistem Pendidikan Nasional. Lembaran Negara Republik Indonesia Tahun 2003, Nomor 4301. Jakarta: Sekretariat Negara.

Republik Indonesia. (2017). Undang Undang No. 5 Tahun 2017 tentang Pemajuan Kebudayaan. Lembaran Negara Republik Indonesia Tahun 2017, Nomor 104. Jakarta: Sekretariat Negara.

Rostiyati, A. (2013). Potensi Wisata di Lampung dan Pengembangannya. Patanjala, 5 (1), 148-162.

Rusmana. D. D. A. (2010). Permainan Congklak: Nilai dan Potensinya bagi perkembangan Kognitif Anak. Patanjala, 2 (3), 538.

Rusnandar, N. 2013. Seba: Puncak Ritual Masyarakat Baduy di Kabupaten Lebak Provinsi Banten. Patanjala, 5 (1), 84.

Sada, S. T. (2019). Ritual Etu Nataia. Artikel milik Dinas Kebudayaan dan Pariwisata Kabupaten Nagekeo.

Seda, T. (19 Juli 2019). Wawancara.

Seda, T. (20 Juli 2019). Wawancara.

Susanti, D. P. 2014. Dampak Permainan Tradisional Kelompok terhadap Perilaku Sosial Siswa Tunarungu. Diakses dari: repository.upi.edu

Watu, A. (18 Juli 2019). Wawancara. 